\title{
Antioxidant, anti-adipocyte differentiation, antitumor activity and anthelmintic activities against Anisakis simplex and Hymenolepis nana of yakuchinone A from Alpinia oxyphylla
}

Rong-Jyh Lin', Chuan-Min Yen' ${ }^{1}$, Tzung-Han Chou ${ }^{2}$, Feng-Yu Chiang ${ }^{3}$, Guey-Horng Wang ${ }^{4}$, Ya-Ping Tseng ${ }^{5}$, Lin Wang ${ }^{6}$, Ting-Wei Huang ${ }^{7}$, Hui-Chuan Wang ${ }^{8}$, Leong-Perng Chan ${ }^{3,9^{*}}$, Hsiou-Yu Ding ${ }^{8^{*}}$ and Chia-Hua Liang ${ }^{4^{*}}$

\begin{abstract}
Background: Alpinia oxyphylla is a common remedy in traditional Chinese medicine. Yakuchinone A is a major constituent of A. oxyphylla and exhibits anti-inflammatory, antitumor, antibacterial, and gastric protective activities.

Methods: Antioxidant and antitumor characteristics of yakuchinone A in skin cancer cells as well as novel mechanisms for the inhibition of adipocyte differentiation, cestocidal activities against Hymenolepis nana adults, and nematocidal activities against Anisakis simplex larvae are investigated.

Results: Yakuchinone A presents the ability of the removal of DPPH.and $\mathrm{ABTS}^{+}$free radicals and inhibition of lipid peroxidation. Yakuchinone A suppresses intracellular lipid accumulation during adipocyte differentiation in 3 T3-L1 cells and the expressions of leptin and peroxisome proliferator-activated receptor $\gamma$ (PPARY). Yakuchinone A induces apoptosis and inhibits cell proliferation in skin cancer cells. The inhibition of cell growth by yakuchinone A is more significant for non-melanoma skin cancer (NMSC) cells than for melanoma (A375 and B16) and noncancerous (HaCaT and BNLCL2) cells. Treatment BCC cells with yakuchinone A shows down-regulation of $\mathrm{BCl}-2$, up-regulation of $\mathrm{Bax}$, and an increase in cleavage poly (ADP-ribose) polymerase (PARP). This suggests that yakuchinone A induces BCC cells apoptosis through the $\mathrm{BCl}$-2-mediated signaling pathway. The anthelmintic activities of yakuchinone A for A. simplex are better than for $\mathrm{H}$. nana.
\end{abstract}

Conclusions: In this work, yakuchinone A exhibits antioxidative properties, anti-adipocyte differentiation, antitumor activity, and anthelmintic activities against $A$. simplex and H. nana.

Keywords: Yakuchinone A, Antioxidant, Adipogenesis, Apoptosis, Hymenolepis nana, Anisakis simplex

\section{Background}

Free radicals include superoxide anion $\left(\mathrm{O}_{2}^{-}\right)$, hydroxyl (HO.), peroxyl (ROO.), alkoxyl (RO.) and nitric oxide, which are oxygen-centered free radicals occasionally known as reactive oxygen species (ROS). Cellular oxidative damage that is caused primarily by ROS is a well-

\footnotetext{
*Correspondence: oleon24@yahoo.com.tw; hsiou221@yahoo.com.tw; tinna_ling@mail.chna.edu.tw

${ }^{3}$ Department of Otolaryngology-Head and Neck Surgery, Kaohsiung Medical University Hospital, Kaohsiung Medical University, Kaohsiung, Taiwan ${ }^{8}$ Institute of Cosmetic Science, Chia Nan University of Pharmacy and Science, Tainan, Taiwan

${ }^{4}$ Department of Cosmetic Science, Chia Nan University of Pharmacy and Science, Tainan, Taiwan

Full list of author information is available at the end of the article
}

established general mechanism for cell as well as tissue injury $[1,2]$. ROS are strongly associated with lipid peroxidation, which leads to the deterioration of the food, and are also involved in a variety of diseases including cellar aging, mutagenesis, carcinogenesis, coronary heart disease, diabetes mellitus, and neurodegeneration [2].

Obesity has become a global health problem due to its association with various metabolic disorders such as type-II diabetes, cardiovascular disease, hypertension, and non-alcoholic fatty liver disease [3,4]. Synthetic antiobesity drugs have been reported to be costly, and some of them also beset with undesirable side effects. Therefore, developing drugs to directly modulate energy 
metabolism without affecting the central nervous system has caused substantial attention $[4,5]$.

Natural/herbal compounds including berberine, resveratrol, and curcumin are known to modulate obesity either through increasing energy expenditure or inhibiting adipocyte differentiation [6-8]. Presently the focus is to develop natural compounds as antioxidants that are possibly used to reduce damage caused by oxidative stress, agedependent diseases, and obesity [9].

Hymenolepis nana is a general occasion of cestode infections, and is found worldwide. In human adults, the tapeworm is more of a nuisance than a health problem, but in small children, $H$. nana is dangerous. It is often seen in children in countries with inadequate sanitation and hygiene. $H$. nana infections are typically asymptomatic but heavy infections also cause headaches, anorexia, weakness, abdominal pain, and diarrhea [10]. H. nana is the only cestode without any intermediate hosts in its life cycle [11]. H. nana infection is typically acquired from eggs in the feces from another infected individual, which are transferred by contaminated food. Eggs hatch in the duodenum, releasing oncospheres that penetrate the mucosa and enter the lymph channels of the villi. Then, oncospheres develop into a cysticercoid, which has a tail and a well formed scolex. About five to six days cysticercoids migrate into the lumen of the small intestine and attach before maturing. Eggs of $H$. nana infect when passed with stool and transfer in contaminated food. Eggs are ingested by an arthropod intermediate host and hatch in the duodenum, releasing oncospheres, and develop into cysticercoid larvae. Upon rupture of the villus, the cysticercoids return to the intestinal lumen, evaginate their scoleces, attach to the intestinal mucosa, and mature into adults that reside in the ileal portion of the small intestine, producing gravid proglottids. The eggs are then passed in stools when released from the proglottids or disintegration of proglottids in the small intestine. An alternate mode of infection consists of internal autoinfection without passing through the external environment. The short life span and rapid course of development also facilitates the spread and ready availability of this worm, but internal autoinfection allows the infection to continue for years $[11,12]$.

Anisakis simplex adult worms mature and release eggs from the primary host. The eggs pass from stool into seawater and are embryonated to form $A$. simplex firststage larvae (AsL1) and subsequently moulted to A. simplex second-stage larvae (AsL2). When larvae are ingested by small crustacean first intermediate hosts, the AsL2 matures into A. simplex third-stage larvae (AsL3) that are subsequently consumed by second intermediate hosts such as marine fish or squid. The AsL3 migrate into the viscera and peritoneal cavity. The degree of migration into the fish musculature depends on environmental conditions and/or the species of parasite and fish condition $[13,14]$. AsL3 are repeatedly transferred between fish and fish through the food chain. Therefore, piscivorous fish accumulate large numbers of AsL3 [14]. Finally, the ingestion of infected fish or squid by a marine mammal (i.e. the final host) leads to the development of fourth-stage larvae and then adults. Humans may be accidental hosts by consuming undercooked and/or raw second intermediate hosts that contain AsL3. A. simplex rarely develop further within the human gastrointestinal tract, instead, by means of proteolytic enzymes, but they typically embed in the gastric or intestinal mucosa and die or invasion the muscular layers of the stomach and intestine to induce allergic reactions and a variety of abdominal symptoms that are characterized as anisakiasis or anisakidosis [15]. The four main clinical syndromes in humans who experience symptomatic anisakidosis include gastric, intestinal, extra-gastrointestinal, and allergic diseases. Anisakidosis is globally recognized as a public health problem, which is relative to Asia and Europe [16,17]. The prevalence of anisakidosis has increased unusually because of the increasing popularity of Japanese cuisine, such as "sushi" and "sashimi". The availability of an anthelmintic compound against $A$. simplex has the potential to shorten the clinical course and prevent mechanical invasion that cause from endoscopic procedures. Because few effective studies for anthelmintic drugs and nature compounds against $A$. simplex, the effectiveness of treatment with anthelmintic agents, antibiotics, anticholinergics, and/or corticosteroids against A. simplex remains controversial [18].

Alpinia oxyphylla is an important traditional Chinese medicinal herb whose fruits are widely used as a tonic, aphrodisiac, anti-salivation, anti-polyuria, and antidiarrhea [19]. The extracts from A. oxyphylla possess neuroprotective activity, anti-tumor, anti-anaphylactic, and inhibition of nitric oxide production $[19,20]$. Yakuchinone A [1-(4'-hydroxy-3'-methoxyphenyl)-7phenyl-3-heptanone], a major pungent ingredient derived from $A$. oxyphylla exhibits anti-inflammatory, antitumor, antibacterial, antiviral, and gastric protective activities [21]. Yakuchinone A has been reported to be a strong inhibitor of prostaglandin biosynthesis in vitro [22]. Moreover, yakuchinone A can act as an anti-tumor promoter as determined by the ability to suppress phorbol ester-induced activation of ornithine decarboxylase (ODC) and inhibits the promotion of papilloma formation in mouse skin [23]. 12-O-tetradecanoylphorbol-13-acetate (TPA)-stimulated superoxide generation and tumor necrosis factor- $\alpha$ (TNF- $\alpha$ ) or interleukin- $1 \alpha$ production in human promyelocytic leukemia (HL-60) cells as well as on DNA binding of activator protein 1 (AP-1) in mouse fibroblast (NIH3T3) cells are also suppressed by yakuchinone A 
[23,24]. Furthermore, yakuchinone A induces apoptotic death in HL-60 cells account for the antiproliferative activity [23]. However, the biochemical mechanisms underlying the antioxidant, anti-obesity, anti-skin cancer effects of yakuchinone $\mathrm{A}$ and its cestocidal effects on $H$. nana and larvicidal effects on $A$. simplex remain unclear. This study confirms the antioxidant and antitumor effects of yakuchinone A and elucidates the novel mechanisms for its inhibition of adipocyte differentiation as well as its anthelmintic activities against $H$. nana and $A$. simplex.

\section{Methods}

\section{Materials}

1,1-Diphenyl-2-picrylhydrazyl (DPPH*), 2,2' -azinobis(3ethylbenzothiazoline-6-sulfonic acid) diammonium salt $\left(\mathrm{ABTS}^{\bullet+}\right)$, 2,5,7,8-tetramethylchroman carboxylic acid (trolox), trichloracetic acid (TCA), 2-thiobarbituric acid (TBA) and 3-isobutyl-1-methylxanthine (IBMX) were purchased form Sigma Chemical Co. (Sigma, St. Louis, MO).

\section{Extraction and isolation}

The "Yizhiren", A. oxyphylla, was supplied from KwongTe Co., Kaohsiung, Taiwan and was identified by professor Hang-Ching Lin of the National Defense Medicinal Center, where a voucher specimen was deposited (CNUPS No.970801). The dry powder of $A$. oxyphylla seed (6.0 kg) was extracted with $95 \%$ ethanol at room temperature. After removal of the solvent by evaporation, the residue (559.0 g) was dissolved in methanol-water (9.5:0.5) and partitioned with $n$-hexane. The methanol (95\%) was removed by evaporation and the residue was then suspended in water and partitioned with ethyl acetate (359.0 g). The ethyl acetate layer was subjected to LH20 Sephadex and eluted with methanol. Each fraction collected from the column was monitored by thin-layer chromatography and the similar fractions were combined to produce 4 fractions. The fraction 3 was further purified by a silica gel and eluted with $n$-hexane-ethyl acetate (9:1, 7.5:2.5, 1:1, 2.5:7.5), ethyl acetate, ethyl acetate-methanol (9:1), methanol to isolate yakuchinone A (276.1 mg). Their structures were confirmed by NMR and mass spectra analysis.

Yakuchinone A: slightly yellow oil; EI/MS $\mathrm{m} / \mathrm{z}$ (rel. int.\%): 312(80, $\left.[\mathrm{M}]^{+}\right), 194$ (6), 179 (45), 161 (14), 151 (33), 137 (100), 119 (23); ${ }^{1} \mathrm{H}-\mathrm{NMR}\left(\mathrm{CDCl}_{3}, 500 \mathrm{MHz}\right)$

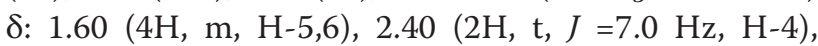
$2.60(2 \mathrm{H}, \mathrm{t}, J=7.0 \mathrm{~Hz}, \mathrm{H}-7), 2.68(2 \mathrm{H}, \mathrm{t}, J=7.6 \mathrm{~Hz}, \mathrm{H}-2)$, $2.82(2 \mathrm{H}, \mathrm{t}, J=7.6 \mathrm{~Hz}, \mathrm{H}-1), 3.86\left(3 \mathrm{H}, \mathrm{s}, \mathrm{OCH}_{3}\right), 6.66(1 \mathrm{H}$, $\mathrm{dd}, J=8.0,2.0 \mathrm{~Hz}, \mathrm{H}-6$ '), $6.68\left(1 \mathrm{H}, \mathrm{d}, J=2.0 \mathrm{~Hz}, \mathrm{H}-2^{\prime}\right)$, 6.83 (1H, d, $J=2.0 \mathrm{~Hz}, \mathrm{H}-5), 7.15 \sim 7.20$ (3H, m, H-3", 4", 5"), $7.26 \sim 7.29$ (2H, m, H-2", 6"); ${ }^{13} \mathrm{C}-\mathrm{NMR}\left(\mathrm{CDCl}_{3}\right.$, $125 \mathrm{MHz}$ ) 8: 210.3 (C-3), 146.3 (C-3'), 143.8 (C-4'), 142.1 (C-1"), 133.0 (C-1'), 128.2 (c-2", 6"), 128.3 (C-3", 5"), 125.7 (C-4"), 120.7 (C-6'), 114.3 (C-5'), 111.0 (C-2'), 55.8
$\left(\mathrm{OCH}_{3}\right), 44.6$ (C-2), 42.9 (C-4), 35.7 (C-7), 30.9 (C-6), 29.5 (C-1), 23.3 (C-5). These data were compared with literature values [25]. The chemical structure of yakuchinone A was shown in Figure 1A. The purity of yakuchinone $\mathrm{A}$ is $99.2 \%$. The solubility of yakuchinone A was $100 \mathrm{mM}$ in dimethylsulfoxide (DMSO).

\section{Assay for free radical scavenging ability against DPPH. and $\mathrm{ABTS}^{+}$}

The radical scavenging activities of yakuchinone $A$ against DPPH $\cdot$ and ABTS ${ }^{+}$radicals were measured by using the method as previously reported [26]. For $\mathrm{DPPH}$ - radical scavenging activity analysis, 5, 10, 20, 30, 40,50 , and $100 \mu \mathrm{M}$ yakuchinone A (10 $\mu \mathrm{l}$ of solution) was mixed with $90 \mu \mathrm{l}$ of DMSO and $900 \mu \mathrm{l}$ of ethanolic $\mathrm{DPPH} \cdot$ solution $(0.1 \mathrm{mM})$. After incubation in darkness at $25^{\circ} \mathrm{C}$ for $30 \mathrm{~min}$, the absorbance $(A)$ was determined at $517 \mathrm{~nm}$ (Hitachi U-2001, Japan). For $\mathrm{ABTS}^{\bullet+}$ radical scavenging activity analysis, $\mathrm{ABTS} \cdot{ }^{+}$was dissolve in water to $7 \mathrm{mM}$. ABTS ${ }^{+}$radical was produced by reacting $\mathrm{ABTS} \cdot{ }^{+}$stock solution with $2.45 \mathrm{mM}$ potassium persulfate, and the mixture stood in the dark at room temperature for $12-16 \mathrm{~h}$. The ABTS $\cdot^{+}$radical solution was diluted to an absorbance of $0.70 \pm 0.02$ at $734 \mathrm{~nm}$ at $30^{\circ} \mathrm{C}$. Each agent $(0.1 \mathrm{ml})$ reacted with $2.9 \mathrm{ml}$ of diluted ABTS.$^{+}$radical solution for $20 \mathrm{~min}$ at $30^{\circ} \mathrm{C}$, and then the absorbance was measured at $734 \mathrm{~nm}$ (Hitachi U-2001, Japan). The TEAC (trolox equivalent antioxidant capacity) of the reagent was calculated by comparing their reactivities to the standard antioxidant, trolox. Ethanol or distilled water was used as negative controls. Trolox was used as a standard antioxidant. The scavenging ability of yakuchinone A or trolox in DPPH . and $\mathrm{ABTS} \cdot{ }^{+}$was calculated using the following equation: radical scavengingability $(\%)=\left(1-A_{\text {sample }} / A_{\text {control }}\right) \times 100$. $\mathrm{EC}_{50}$ values were estimated from the percent inhibition versus concentration plot derived from the percentage scavenging activity. This data was shown as mean values \pm standard deviation $(n=3)$.

\section{Determination of antioxidant effect on liposome peroxidation}

The effect on liposome peroxidation was assayed by measuring concentrations of thiobarbituric acid reactive substances (TBARS). Liposomes were prepared according to the method of Chou et al. [27]. In brief, the liposomes were obtained by dispersing lipids in demineralized water (1:10). For the assay, $32 \mu \mathrm{l}$ of suspension of liposomes was incubated together with $11 \mu \mathrm{l}$ of $10 \mathrm{mM} \mathrm{FeSO}_{4}, 11 \mu \mathrm{l}$ of $10 \mathrm{mM}$ ascorbic acid and appropriate amounts of different concentrations $(5,10,20,30,40,50$ and $100 \mu \mathrm{M})$ of yakuchinone A, trolox and rutin in $1.515 \mathrm{ml}$ of $50 \mathrm{mM}$ $\mathrm{Na}_{2} \mathrm{HPO}_{4}-\mathrm{NaH}_{2} \mathrm{PO}_{4}$ buffer, $\mathrm{pH} 7.4$ (2.5 ml final solution) at $37^{\circ} \mathrm{C}$ for $1 \mathrm{~h}$. Lipid peroxidation was terminated by the 


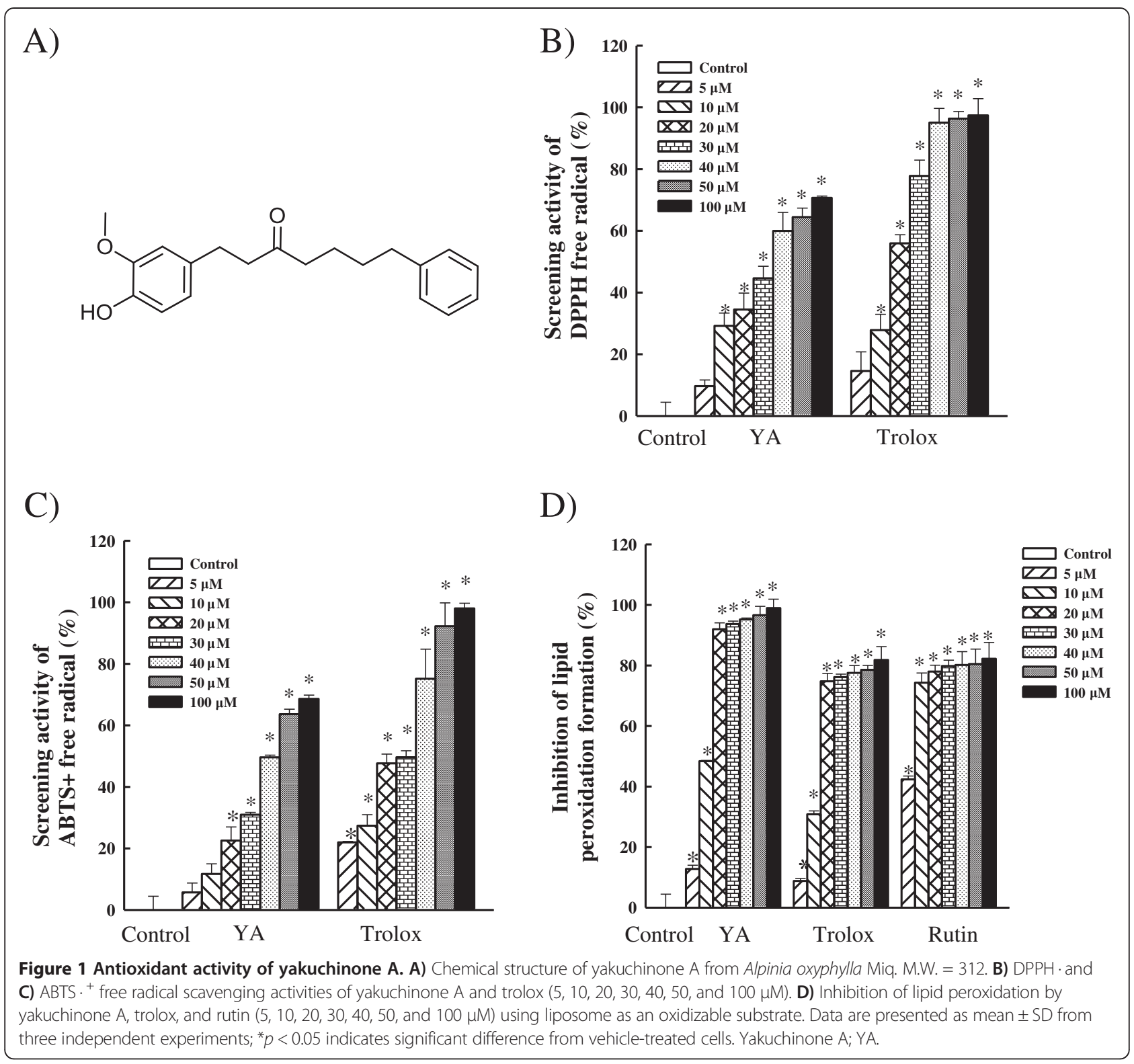

reaction of $0.8 \mathrm{ml}$ of $1 \%$ TBA and 10\% TCA and $106 \mu \mathrm{l}$ of $0.1 \mathrm{M}$ ethylene diamine-tetraacetic acid disodium salt dehydrate at $100^{\circ} \mathrm{C}$ for $20 \mathrm{~min}$. After cooling and centrifugation ( $2600 \mathrm{~g}$ for $10 \mathrm{~min}$ ), the malonaldehyde (MDA)-TBA complex was determined by measuring the absorbance $(A)$ at $532 \mathrm{~nm}$. A control with DMSO instead of sample was also analyzed and expressed no activity. Trolox and rutin were utilized as standards. The percentage inhibition was calculated using the following equation: Inhinition of lipid peroxidation $(\%)=$ $\left(1-A_{\text {sample }} / A_{\text {control }}\right) \times 100 . \mathrm{EC}_{50}$ values were estimated from the percentage inhibition versus concentration plot. This data was shown as mean values \pm standard deviation $(n=3)$.

\section{Cell lines}

Human epidermoid carcinoma A431, human oral squamous cell carcinoma SCC25. human skin malignant melanoma A375, mouse melanoma B16, mouse leukemic monocyte macrophage RAW 264.7, mouse normal embryonic liver BNLCL2 cells, and 3 T3-L1 preadipocytes were purchased from the American Type Culture Collection (Rockville, MD). Human basal cell carcinoma $\mathrm{BCC}$ and human premalignant keratinocytic $\mathrm{HaCaT}$ cells were kindly donated by Prof. Hamm-Ming Sheu (National Cheng Kung University Medical College, Tainan, Taiwan). Cells were cultured in medium supplemented with 10\% fetal bovine serum (Hazelton Product, Denver, $\mathrm{PA})$ and $1 \%$ penicillin-streptomycin at $37^{\circ} \mathrm{C}$ in $5 \% \mathrm{CO}_{2}$ 
humidified atmosphere; specifically, A431, A375, B16, HaCaT, RAW 264.7, BNLCL2, and 3 T3-L1 cells were maintained in DMEM medium (GIBCO, Grand Island, NY), BCC cells in RPMI medium, and SCC25 in DMEM/ F12 medium supplemented with $0.4 \mu \mathrm{g} / \mathrm{ml}$ hydrocortisone (Sigma, St. Louis, MO).

\section{Adipocyte differentiation}

Cultivation of 3 T3-L1 cells and their conversion to adipocytes were carried out according to the method as described previously [28]. To induce differentiation, four day postconfluent 3 T3-L1 preadipocytes were stimulated for $72 \mathrm{~h}$ in $10 \% \mathrm{FBS} / \mathrm{DMEM}$ with containing the MDI hormone mixture (0.5 mM IBMX, $1 \mu \mathrm{M}$ dexamethasone, and $10 \mu \mathrm{g} / \mathrm{ml}$ of insulin) in six-well plates. After four days, the medium was replaced with $10 \%$ FBS/DMEM medium containing $10 \mu \mathrm{g} / \mathrm{ml}$ of insulin. The medium was replaced with fresh medium $(10 \%$ FBS/DMEM, $10 \mu \mathrm{g} / \mathrm{ml}$ of insulin) every two days until analysis on day eight. Yakuchinone A $(5 \mu \mathrm{M})$ was added during the differentiation process.

\section{Oil Red $O$ staining}

Differentiated 3 T3-L1 cells were stained using the Oil Red O method [29] for adipocyte lipid accumulation. At day eight of differentiation, the cells were washed with PBS and fixed with $10 \%$ formaldehyde for $2 \mathrm{~h}$. The fixed cells were washed with $60 \%$ isopropanol, and stained with $0.2 \%$ Oil Red $\mathrm{O}$ for $10 \mathrm{~min}$. The plates were rinsed three times with water and examined under a phase contrast inverted light microscope (Nikon, TE2000-U, Japan). After thorough washing with water and evaporation of excess water, Oil Red O was extracted in isopropyl alcohol and the absorbance was monitored at $520 \mathrm{~nm}$ (BioTek, Synergy $\left.{ }^{\mathrm{Tm}} 2\right)$.

\section{Cell viability}

Cells $\left(1 \times 10^{5}\right.$ cells $\left./ \mathrm{ml}\right)$ were plated in $100 \mu \mathrm{l}$ of 96 -well multidishes and treated with a series of concentrations $(5,10,20,30,40$, and $50 \mu \mathrm{M})$ of yakuchinone A or vehicle control (DMSO) for $72 \mathrm{~h}$. The control groups were treated with DMSO, and the final DMSO concentration did not exceed $0.1 \%$. The cell viability was measured by performing the MTT [3-(4,5-dimethyl-thiazol-2-yl)-2,5diphenyl-tetrazolium bromide] assay [30]. The $\mathrm{IC}_{50}$ values were calculated from the agent concentrations that yielded a cell viability of $50 \%$.

\section{Cell morphological changes}

Cells $\left(1 \times 10^{5}\right.$ cells $\left./ \mathrm{ml}\right)$ were plated in 24 -well plates then treated with vehicle control (DMSO) or yakuchinone A $(20 \mu \mathrm{M})$ for $72 \mathrm{~h}$. Cells in each well were washed once with $1 \times$ PBS, and analysis was performed using a phase contrast inverted light microscope (Nikon, TE2000-U, Japan). To assess specific apoptosis, after incubation, cells were washed by PBS and fixed with $4 \%$ paraformaldehyde and stained with Hoechst $33342(0.1 \mu \mathrm{g} / \mathrm{ml})$ (Sigma) at $37^{\circ} \mathrm{C}$ for $10 \mathrm{~min}$ in the dark. The nuclear morphology changes were viewed under a fluorescent microscope (Nikon, TE2000-U, Japan).

\section{RNA isolation and reverse transcription-polymerase chain reaction (RT-PCR) analysis}

3 T3-L1 cells were treated with vehicle control (DMSO) or yakuchinone $\mathrm{A}(5 \mu \mathrm{M})$ during the differentiation process. BCC cells $\left(1 \times 10^{5}\right.$ cells $\left./ \mathrm{ml}\right)$ were treated with vehicle control (DMSO) or yakuchinone A $(20 \mu \mathrm{M})$ for 24 and $48 \mathrm{~h}$. Total RNA was prepared from cells using the Trizol reagent (Invitrogen, Carlsbad, CA, USA), and a RTPCR was conducted using $3 \mu \mathrm{g}$ of total RNA and the Superscript cDNA Preamplification System (Weiterstadt, Germany) according to the manufacturers' instructions. The following primers were utilized: right primer 5 '-GCT CTA GAC GTG ACA ATC TGT CTG AGG TCT GTC AT-3' and left primer 5'-CGG CAT CCG TTG TCG GTT TCA CAA ATG CCT TGC AGT G-3' for PPAR $\gamma$ (870 bp), right primer 5'-CAT CTG CTG GCC TTC TCC AA-3' and left primer 5'-ATC CAG GCT CTC TGG CTT CTG-3' for leptin (71 bp), right primer 5' AGA TGT CCA GCC AGC TGC ACC TGA C-3' and left primer 5'-AGA TAG GCA CCC AGG GTG ATG CAA GCT-3' for bcl-2 (367 bp), right primer 5' -AAG CTG AGC GAG TGT CTC AAG CGC-3' and left primer 5'-TCC CGC CAC AAA GAT GGT CAC G-3' for bax (366 bp), and right primer $5^{\prime}$-ACC CAC ACT GTG CCC ATC TA-3' and left primer 5'-CGG AAC CGC TCA TTG CC-3' for $\beta$-actin (286 bp). The amplified RT-PCR products were analysed in $2 \%$ agarose gels, visualized by ethidium bromide staining and photographed under ultraviolet light.

\section{Western blotting}

Cells $\left(1 \times 10^{5}\right.$ cells $\left./ \mathrm{ml}\right)$ were treated with vehicle control (DMSO) or yakuchinone A $(20 \mu \mathrm{M})$ for $72 \mathrm{~h}$. Then, cells were washed with $\mathrm{PBS}$, and lysed in lysis buffer [50 mM Tris-HCl, pH 7.5, 1\% Triton X-100, 5 mM EGTA (ethylene glycol-bis(2-aminoethylether)$N, N, N, N^{\prime}$-tetraacetic acid), $150 \mathrm{mM} \mathrm{NaCl}$ and $1 \mathrm{mM}$ phenylmethylsulfonyl fluoride (PMSF)]. After centrifugation $(10,000 \mathrm{~g}, 10 \mathrm{~min})$, supernatants were collected. The cell lysates containing $40 \mu \mathrm{g}$ of solubilized protein were subjected to $12 \%$ sodium dodecyl sulfate-polyacrylamide gel electrophoresis (SDS-PAGE) and electrophoretically transferred to nitrocellulose membranes. The membranes were blocked in 5\% skim milk. Blots were incubated with the antibodies against Bcl-2, Bax, PARP and $\beta$-actin (Santa Cruz, CA). The membranes were incubated with the appropriate secondary antibody conjugated with horseradish peroxidase (Bio-Rad, Hercules, CA). Blotted antibodies 
were visualized by chemiluminescence method (ECL kit, Amersham).

\section{Preparation of $H$. nana adult worms}

$H$. nana adult worms were obtained from each part of the intestines of wild type mice, purchased from Lin's farm in Fengshan, Kaohsiung, Taiwan. These parts of the intestine were duodenum, jejunum, ileum, colon and rectum. The $H$. nana had an average length of 5-50 mm and was collected using a needle with a blunt tip, before being placed in Petri dishes with $0.9 \% \mathrm{NaCl}$ and gentamycin $(10 \mathrm{mg} / \mathrm{ml})$. They were then washed several times. The adult worms were individually observed under an inverted microscope, with subsequent discarding of those that exhibited internal or external damage. The adult worms were then identified by their morphological features, divided into groups and placed in 24-well plates contained cultivated media RPMI-1640 plus 20\% FBS, $\mathrm{pH} 7.4$, in an atmosphere of $95 \% \mathrm{O}_{2} / 5 \% \mathrm{CO}_{2}, 37^{\circ} \mathrm{C}$. These culture conditions have been shown to maximize the development and survival of $H$. nana.

\section{Assay of cestocidal activity of oscillation and peristalsis test on H. nana}

The above $H$. nana cultivated media were supplemented with L-glutamine $(2 \mathrm{mM})$, penicillin $(100 \mathrm{IU} / \mathrm{ml})$, streptomycin $(100 \mathrm{mg} / \mathrm{ml})$ and amphotericin $B(0.25 \mu \mathrm{g} / \mathrm{ml})$, and then the effects of yakuchinone A at concentrations of 10 , 50 and $100 \mu \mathrm{M}$ were tested. The survival and mobility of the adult worm were assessed at 2, 4, 6, 12, 24, 48, and $72 \mathrm{~h}$ using a stereomicroscope. They were observed for their spontaneous motility and evoked responses at 2, 4, 6, $12,24,48$, and $72 \mathrm{~h}$ using a stereomicroscope. The oscillation and peristalsis states of adult worms were scored blindly by two investigators. Cestode activity was scored by monitoring both oscillation and peristalsis. Oscillation was scored of movement at scolex and neck for each second for 30 seconds, and then the highest score was 30 . Peristalsis was record the contraction real times at scolex and neck. All data were compared with the initial time before the test compounds had been added. Worms death and complete standstill as determined by none any oscillation and peristalsis changes for 30 seconds were identified. The mortality was recorded after ascertaining that the worms neither moved when shaken vigorously nor when dipped in warm medium [31].

\section{A. simplex larvae preparation}

The AsL3 were obtained from the muscle and peritoneum of fresh Trichiurus lepturuss (largehead hairtail, Atlantic cutlassfish) that were purchased from the fish market of Kaohsiung, Taiwan. The AsL3 had an average length of 20-22 mm, and were collected using a needle with a blunt tip, placed in Petri dishes with $0.9 \% \mathrm{NaCl}$ and washed several times. The majority of the larvae were encysted, but they quickly became excysted upon washing in $\mathrm{NaCl}$ solution. They were individually observed under an inverted microscope, with subsequent discarding of those that exhibited internal or external damage. The larvae were then identified by morphological features, divided into groups and placed in 24well plates contained cultivated media RPMI-1640 plus $20 \%$ FBS, pH 4.0, in an atmosphere of $95 \% \mathrm{O}_{2} / 5 \% \mathrm{CO}_{2}$, $37^{\circ} \mathrm{C}$. These showed culture conditions demonstrated to provide for the maximum development and survival of $A[18,32]$.

\section{Assay of nematocidal activity on A. simplex}

The above AsL3 cultivated media were supplemented with L-glutamine $(2 \mathrm{mM})$, penicillin $(100 \mathrm{IU} / \mathrm{ml})$, streptomycin $(100 \mathrm{mg} / \mathrm{ml})$ and amphotericin B $(0.25 \mu \mathrm{g} / \mathrm{ml})$, and tested of yakuchinone A for 10, 100, and $200 \mu \mathrm{M}$. The survival and mobility of the larvae were assessed at 2, 4, 8, 12, 24, 48 and $72 \mathrm{~h}$ using a stereomicroscope. Two investigators blindly scored the larvae as dead, with poor mobility or with normal mobility. The percentage losses of spontaneous motion during 3 min periods immediately after incubation and complete standstill were determined by stimulation 4-5 h later (defined as death). The mortality was recorded after ascertaining that the worms neither moved when shaken vigorously nor when dipped in warm medium. The nematocidal activity was modified according to a scoring system that was developed by Kiuchi et al. [33] and Lin et al. [18].

\section{Statistical analysis}

The results are expressed as mean \pm standard deviation (SD). Statistical differences were estimated by one-way analysis of variance (ANOVA) followed by Dunnett's test or the Tukey-Kramer test. A $p$ value of 0.05 was regarded as significant. The data were analyzed and the figures plotted using software (SigmaPlot Version 8.0 and SigmaStat Version 2.03, Chicago, IL).

\section{Results and discussion}

\section{Free radical scavenging activity of yakuchinone $A$}

The DPPH . and ABTS $\cdot^{+}$radical has been widely used for assessment of radical scavenging because of the easy and convenient consideration [34]. The soluble free radical DPPH - is well known as a good hydrogen abstractor that yields DPPH-H as a by-product. Thus, the scavenging of DPPH radicals by phenols is effective. The antioxidant activity of yakuchinone A and trolox (a positive control) was measured based on scavenging activities for stable DPPH radical as presented in Figure 1B. With increasing doses from 5 to $100 \mu \mathrm{M}$ of yakuchinone A and trolox, the values of DPPH.scavenging activity were $9.6 \%, 29.2 \%, 34.5 \%, 44.6 \%, 60.0 \%, 64.5 \%$, and $70.7 \%$ for 
yakuchinone A and 14.5\%, 27.8\%, 55.9\%, 77.7\%, 95.0\%, $96.3 \%$, and $97.4 \%$ for trolox, respectively. The $\mathrm{EC}_{50}$ values of yakuchinone A for the scavenging of DPPH. radicals were 33.5 (yakuchinone A) and $17.9 \mu \mathrm{M}$ (trolox). The generation of ABTS.$^{+}$involves the direct production of the blue/green ABTS ${ }^{+}$chromophore through the reaction of potassium persulfate and ABTS. The addition of hydrogen-donating antioxidants to the preformed radical reduces it to ABTS [35]. Figure $1 \mathrm{C}$ shows the scavenging activity of yakuchinone A towards ABTS ${ }^{+}$. As increasing doses of $5,10,20,30,40,50$, and $100 \mu \mathrm{M}$ of yakuchinone A and trolox, the values of ABTS ${ }^{+}$scavenging capacity were $5.7 \%, 11.7 \%, 22.5 \%, 31.0 \%, 49.6 \%, 63.6 \%$, and $70.6 \%$ for yakuchinone A and 21.9\%, 27.3\%, 47.6\%, 49.6\%, 75.1\%, $92.2 \%$, and $98.0 \%$ for trolox, respectively. The $\mathrm{EC}_{50}$ values for the scavenging of ABTS $\cdot{ }^{+}$-radicals were 40.2 (yakuchinone A) and $30.1 \mu \mathrm{M}$ (trolox). The extent of decolorization as percentage inhibition of the ABTS.$^{+}$ radical cation was proportional to the concentration of antioxidants and calculated relative to the reactivity of trolox as a standard (TEAC). The TEAC value derived from the dose-response curve for yakuchinone A was $3.4 \mathrm{mM}$ of trolox/g. These results suggest that yakuchinone A exhibits an antioxidant capacity to scavenge DPPH. and ABTS $\cdot{ }^{+}$free radicals.

\section{Potential of yakuchinone A to inhibit lipid peroxidation}

The antioxidant action is assessed by inhibiting the damage caused by free radicals and the mechanisms involved in many human diseases such as hepatotoxicities, hepatocarcinogenesis, diabetes, malaria, acute myocardial infarction, and skin cancer to include lipid peroxidation as a main source of membrane damage [9]. Lipid peroxidation in biological systems has been thought to be a toxicological phenomenon that leads to various pathological consequences. MDA formed from lipid peroxidation of unsaturated phospholipid reacts with TBA to produce a pink MDA-TBA adducts. MDA is reactive and active in crosslinking with DNA and proteins and damages liver cells [36]. Phospholipids are believed to be present in high amounts in cell membranes [37]. The phospholipid prepared as a liposome was used to evaluate the effect of yakuchinone A on liposome peroxidation to investigate yakuchinone $\mathrm{A}$ in a biological system. Figure $1 \mathrm{D}$ presents the inhibition of lipid peroxidation by yakuchinone A $(5,10,20,30,40,50$, and $100 \mu \mathrm{M})$ depended on dose. The $\mathrm{EC}_{50}$ values of the inhibition of lipid peroxidation efficiency by yakuchinone A, trolox and rutin were 10.3, 14.3 and $6.2 \mu \mathrm{M}$, respectively. Although the inhibition of lipid peroxidation activity by yakuchinone $\mathrm{A}$ was weaker than by rutin, the inhibition efficiency of yakuchinone A exceeded trolox. The MDA lowering effect of yakuchinone A indicates a protective action against lipid peroxidation of unsaturated phospholipids.

\section{Inhibition of lipid accumulation by yakuchinone $A$ in 3 T3-L1 adipocytes}

Numerous studies show that obesity may induce systemic oxidative stress, and the increase in ROS in adipocytes contributes to deregulated expression of inflammatory cytokines such as tumor necrosis factor- $\alpha$, which may be an early instigator of the obesity-associated diabetes and cardiovascular disease $[37,38]$. This work demonstrates that yakuchinone A exhibits anti-oxidation activities, suggesting yakuchinone A has an inhibitory effect on adipogenesis. 3 T3-L1 adipogenic differentiation requires a network of adipogenic markers [3]. We examined the ability of the yakuchinone $\mathrm{A}$ to prevent adipogenesis in 3 T3-L1 adipocytes. The amount of accumulated intracellular lipid droplets were compared in differentiated 3 T3-L1 cells after treatment in a MDI mixture and differentiated cells. The amount of intracellular lipid droplets increased in differentiated 3 T3- L1 cells, as shown by the Oil Red O staining (Figure 2A). However, incubation of differentiated cells with low concentration of yakuchinone A $(5 \mu \mathrm{M})$ decreased MDI-induced lipid accumulation. This result was further supported by quantitative spectrophotometric analysis of cellular neutral lipid content. Figure 2B shows lipid accumulation was significantly inhibited in the presence of $5 \mu \mathrm{M}$ yakuchinone A. The level of lipid accumulation over eight days was $19.2 \%$ of the MDI-treated positive control cells. Adipocytokines are adipocytederived hormones, such as leptin and adiponectin, which modulated hepatic and peripheral lipid and glucose metabolism [4]. The amount of leptin secreted in the adipose tissue is positively correlated with the lipid content and adipocyte size [4]. Furthermore, previous research has established that adenosine $5^{\prime}$-phosphate-activated protein kinase (AMPK) and peroxisome proliferator-activated receptor $\gamma$ (PPAR $\gamma$ ) appears to be involved in adipocyte differentiation and maturation. This can be potential drug targets for the treatment of obesity [3]. We evaluated the yakuchinone A-induced changes in the expression of adipose tissue genes associated with adipogenesis through RT-PCR analyses. As shown in Figure 2C, addition of yakuchinone A $(5 \mu \mathrm{M})$ suppressed the expression of leptin and PPARY significantly as revealed by RT-PCR. These results suggest that yakuchinone $A$ inhibits and adipogenesis due in part to the inhibition of angiogenesis. These events may be mediated, in part, through antioxidative properties of yakuchinone A responsible for inhibition of angiogenesis.

\section{Effect of yakuchinone A on cell viability and skin cancer cell apoptosis}

Previous report have demonstrated that yakuchinone A exhibits no cytotoxicity against human lung adenocarcinoma A549 cells, human colorectal carcinoma HT-29 


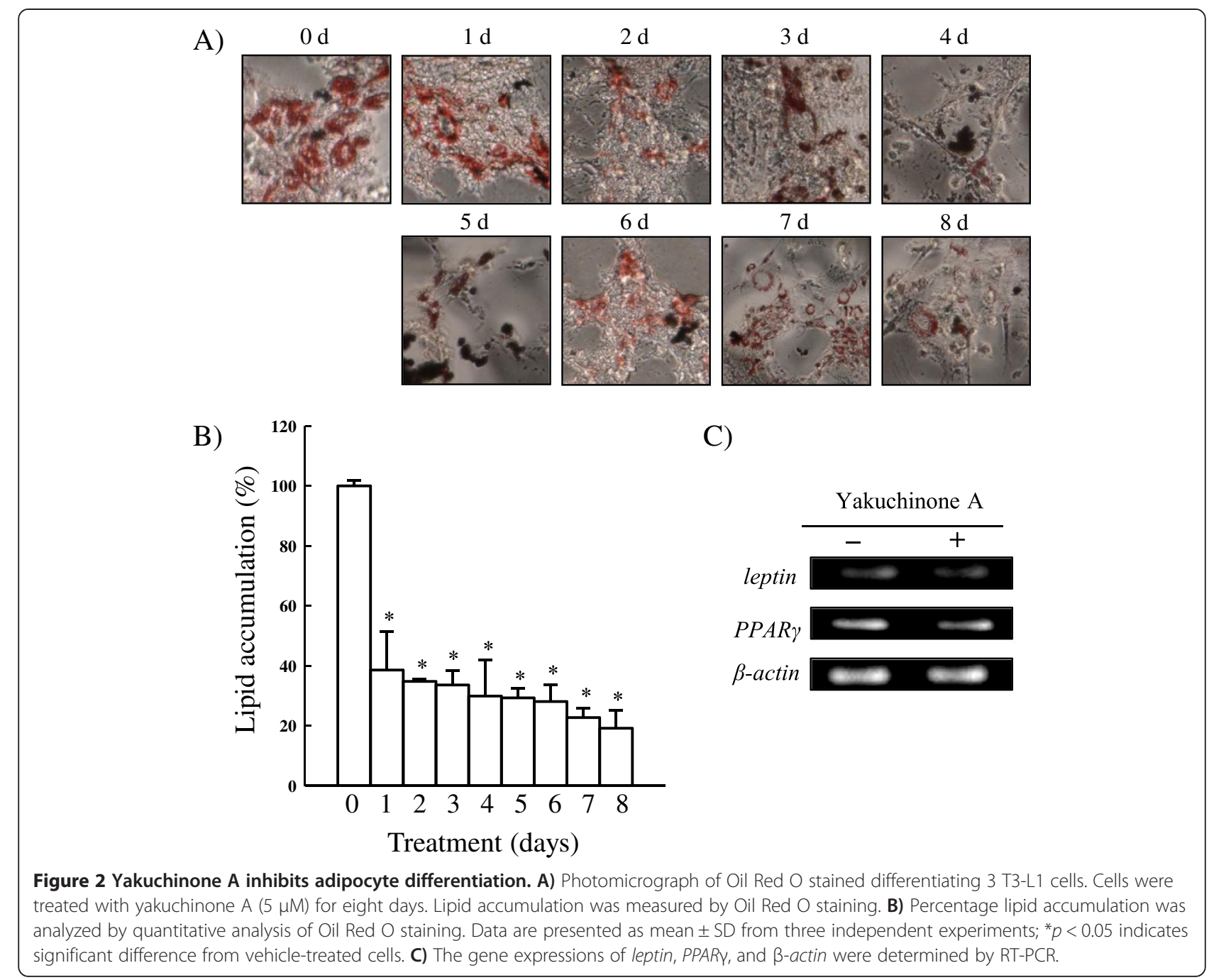

cells, and human gastric cancer SGC-7901 cells at a concentration of $10 \mu \mathrm{g} / \mathrm{ml}$ [39], but yakuchinone A induces apoptotic death in HL-60 cells [23]. Nevertheless, cytotoxic effects of yakuchinone A on skin cancer cells remain poorly understood. In this work, the inhibition potential of yakuchinone A on human skin cancer cells (epidermoid carcinoma A431 cells, basal cell carcinoma BCC cells, squamous cell carcinoma SCC25 cells and malignant melanoma A375 cells) and mouse melanoma B16 cells was determined by MTT assay and morphological change. Treatment these cells with yakuchinone A $(5,10,20,30,40$, and $50 \mu \mathrm{M})$ for $72 \mathrm{~h}$ resulted in a dose-dependent significant cell death (Figure 3). The $\mathrm{IC}_{50}$ values of yakuchinone A were 13.3, 11.3, 18.7, 23.8, and $40.0 \mu \mathrm{M}$ for A431, BCC, SCC25, A375, and B16 cells, respectively. Moreover, after $72 \mathrm{~h}$ treatment with yakuchinone A $(5,10,20,30,40$, and $50 \mu \mathrm{M})$, the $\mathrm{IC}_{50}$ values of yakuchinone A against noncancerous cells (human premalignant keratinocytic $\mathrm{HaCaT}$ cells and mouse embryonic liver BNLCL2 cells) and mouse leukemic monocyte macrophage RAW 264.7 cells were 22.2, 32.2, and $46.4 \mu \mathrm{M}$, respectively (Figure 4). Yakuchinone A appeared to have a more potent inhibitory effect on non-melanoma skin cancer (NMSC) cells (A431, BCC, and SCC25) and cell viability than in melanoma cells (A375 and B16), noncancerous cells (HaCaT and BNLCL2), and RAW 264.7 cells. Previous studies have demonstrated that yakuchinone A has a phenolic diarylheptanoid moiety with a carbonyl functional group to suggest that yakuchinone $\mathrm{A}$ is anticipated to exhibit potential cancer chemopreventive activities [39]. These experimental data further suggest that yakuchinone A has an antioxidant affect that exhibits less toxic to noncancerous cells and selective cytotoxicity to NMSC cells.

The cell death induction by yakuchinone A was further confirmed by cellular morphological examination. After exposure of $20 \mu \mathrm{M}$ yakuchinone A to BCC cells at $72 \mathrm{~h}$, distinct cytoplasmic shrinkage, cell bodies became rounded and detached from the surface under phasecontrast-inverted microscopic examination (Figure 5A). 


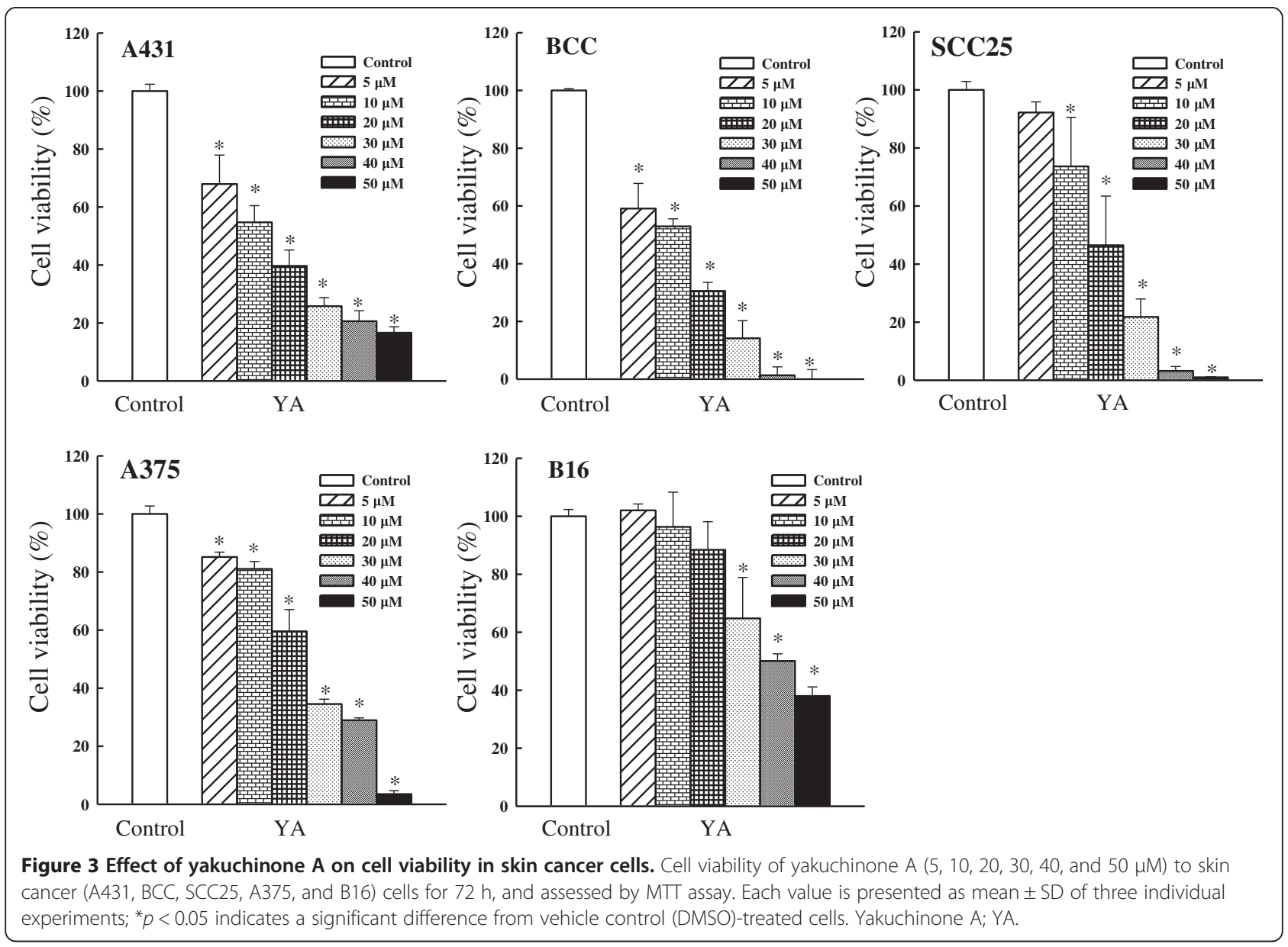

Treatment of BCC cells with yakuchinone A showed chromatin condensation and nuclear fragmentation by Hoechst 33342 staining under a fluorescent microscope, indicating apoptosis (Figure $5 \mathrm{~A}$ ). Bcl-2 family members are major apoptosis-regulating proteins [40]. Given that the Bcl-2 family proteins are known mediators of mitochondrial functions, expression levels of antiapoptotic protein $\mathrm{Bcl}-2$, and pro-apoptotic protein $\mathrm{Bax}$ were determined. Bcl-2 expression was time-dependent decreased; whereas, bax was increased and investigated by RT-PCR following the exposure of BCC cells to yakuchinone $\mathrm{A}(20 \mu \mathrm{M})$ for 24 and $48 \mathrm{~h}$ (Figure $5 \mathrm{~B}$ ).

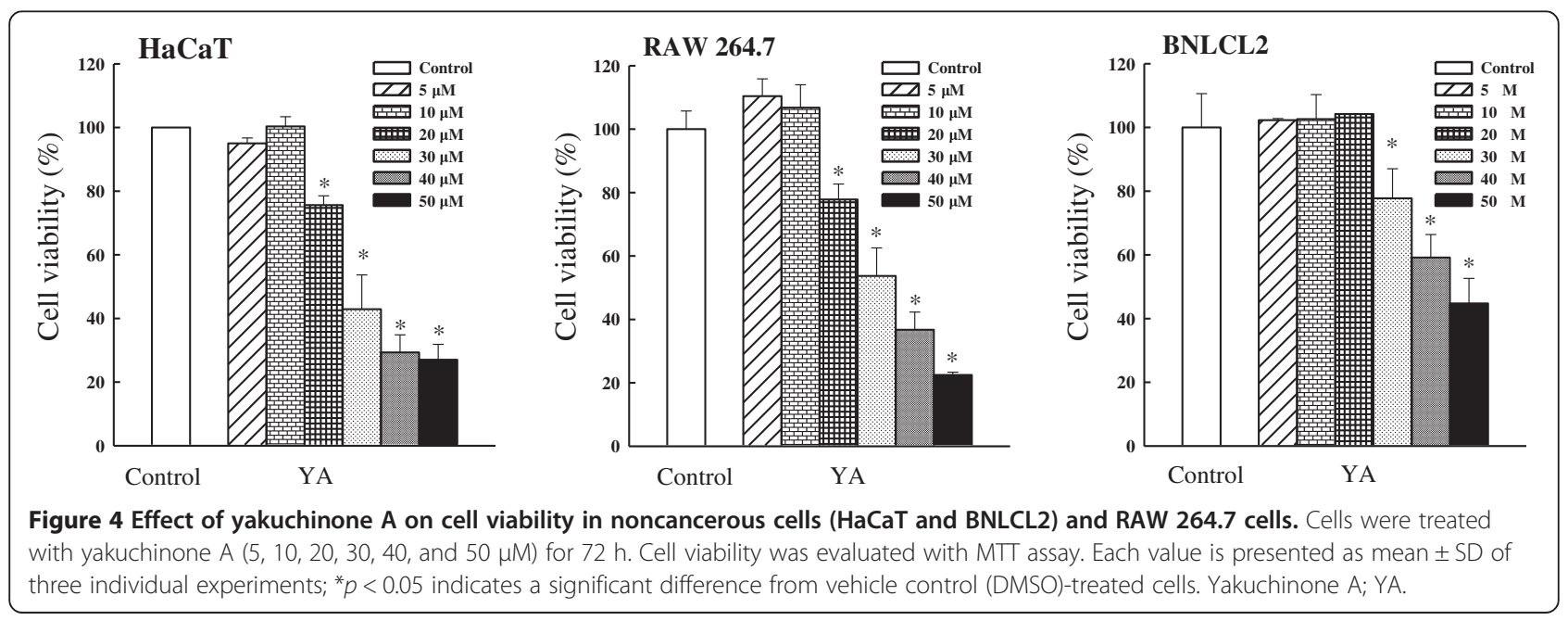


A)
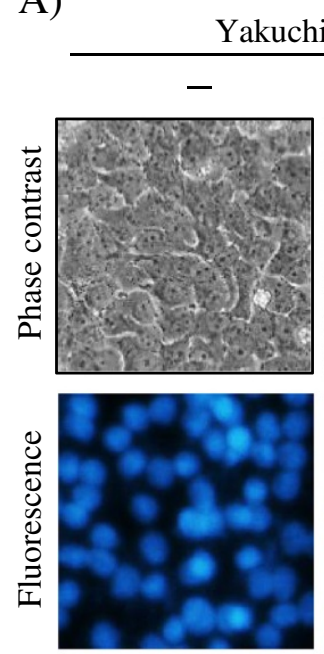

B)

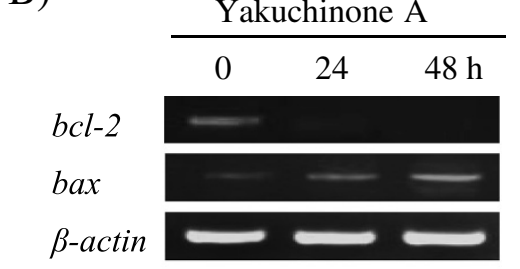

C)

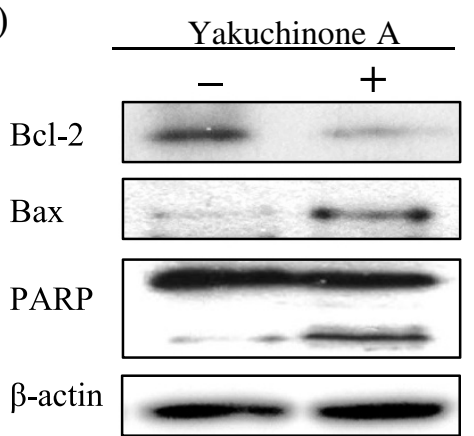

Figure 5 Expression of $\mathrm{BCl}-2$ and bax-dependent apoptotic pathway in BCC cells after yakuchinone A treatment. A) Morphological changes induced by yakuchinone A in BCC cells. BCC cells were treated with yakuchinone A (20 $\mu$ M) and vehicle control (DMSO) for 72 h, and then the nuclear was stained with Hoechst 33342. Apoptotic cells (arrows) were characterized by cellular shrinkage and rounded cell bodies (phase-contrast-inverted microscopic, 200x). Under a fluorescent microscope, apoptotic cells (arrows) were characterized by marked nuclear condensation, shrinking and fragmentation (200x). B) Effect of yakuchinone A on bcl-2 and bax expressions. BCC cells were treated with yakuchinone $\mathrm{A}(20 \mathrm{\mu M})$ and vehicle control (DMSO) for 24 and $48 \mathrm{~h}$, and the bcl-2, bax and $\beta$-actin expressions were determined by RT-PCR. C) Expressions of $\mathrm{BCl}-2, \mathrm{Bax}$ and PARP on cells after yakuchinone A treatment. BCC cells were treated with (+) or without (-) yakuchinone $\mathrm{A}$ $(20 \mu \mathrm{M})$ for $72 \mathrm{~h}$, and the Bcl-2, Bax, PARP and $\beta$-actin expression were assessed by Western blotting.

These experimental results are consistent with the yakuchinone A $(20 \mu \mathrm{M})$ applied for $72 \mathrm{~h}$ by Western blotting (Figure 5C). Cleavage of the poly (ADP-ribose) polymerase (PARP) in BCC cells after yakuchinone A treatment gave further evidence that apoptosis happened because the active form of PARP, a protein associated with DNA repair, is considered as a hallmark of apoptosis. These results suggest that yakuchinone A-induced cell death is mainly due to apoptosis.

\section{Cestocidal activity against $H$. nana}

Figure 6 plots the time course of oscillation and peristalsis during yakuchinone A treatment. In oscillation activity assay, the percentage of oscillation for the vehicle control ( $0.1 \%$ DMSO) decreased by about $18 \%$ from $72 \mathrm{~h}$ cultivation (Figure 6A). However, in the peristalsis activity assay, the percentage of peristalsis for the vehicle control (0.1\% DMSO) decreased by $31 \%$ from 72 h cultivation (Figure 6B). The change of peristalsis of $H$. nana was more sensitive than that of oscillation via treatment of vehicle. Treatment with 10,50 , and $100 \mu \mathrm{M}$ yakuchinone A has a greater effect on peristalsis than oscillation for 24 , 48, and $72 \mathrm{~h}$. Peristalsis activity disappeared before oscillation activity was lost when $H$. nana was dead. In fact, $H$. nana has no peristalsis or oscillation effect when dead.

In the oscillation activity assay (Figure 6A), exposure to $100 \mu \mathrm{M}$ yakuchinone $\mathrm{A}$ for $72 \mathrm{~h}$ caused the maximum effect of $27 \%$ of $H$. nana. Treatment with yakuchinone A (a concentration of $50,100 \mu \mathrm{M}$ but not $10 \mu \mathrm{M}$ ) for 48 and $72 \mathrm{~h}$ reduced the oscillation up to $21 \%$ and $31 \%$ or $47 \%$ and $73 \%$, respectively. Yakuchinone A slowly reduced oscillation from 2 to $72 \mathrm{~h}$ but did not cause death. Yakuchinone A reduced the oscillation activity of $H$. nana in a time- and dose-dependent manner for 24 to $72 \mathrm{~h}$ (Figure 6A).

The effect of yakuchinone A over time of the peristalsis activity of $H$. nana was investigated (Figure 6B). For peristalsis activity assay, a dose- and time-dependent effect for 24 to $72 \mathrm{~h}$ was also observed by treatment with yakuchinone A. Treatment for $48 \mathrm{~h}$ with 50 and $100 \mu \mathrm{M}$ yakuchinone A stopped peristalsis in more than approximately 21 to $25 \%$ of worms. Yakuchinone A at 50 and $100 \mu \mathrm{M}$ slowly reduced peristalsis from 2 to $72 \mathrm{~h}$. Treatment with $10 \mu \mathrm{M}$ yakuchinone A for $72 \mathrm{~h}$ reduced peristalsis to $22 \%$ (Figure $6 \mathrm{~B}$ ). This effect on peristalsis is stronger than on oscillation activity. The above performances were the same for other concentrations of yakuchinone $\mathrm{A}$ in peristalsis activity.

\section{Nematocidal activity against $A$. simplex}

In the first series of experiments, the larvicidal effects were used to study the ability of yakuchinone A to alter survival of AsL3. The time course of the yakuchinone A-induced loss of mobility on AsL3 was also studied. 

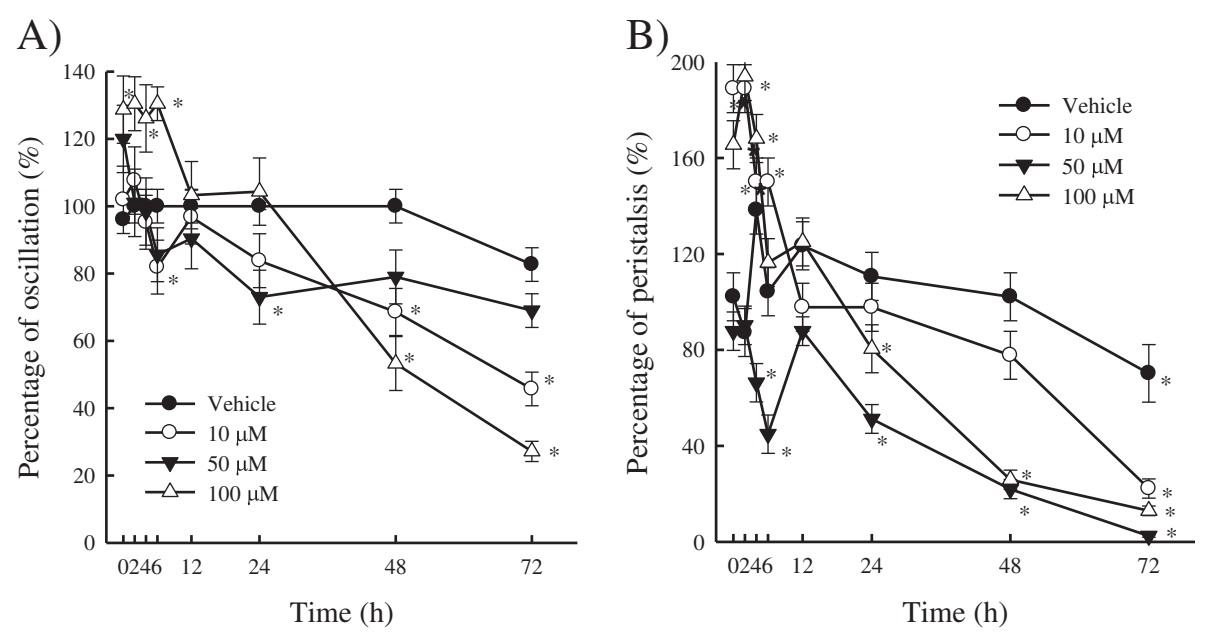

Figure 6 Effect of yakuchinone A on $\mathbf{H}$. nana. Treatment with various concentrations of yakuchinone A (10, 50, and $100 \mu \mathrm{M})$ with incubation times of $2,4,6,12,24,48$, and $72 \mathrm{~h}$ on $\mathrm{H}$. nana, respectively. Time course of effect on oscillation $\mathbf{A}$ ) and peristalsis $\mathbf{B}$ ) of $H$. nana of yakuchinone A presented as percentages. Vehicle is $0.1 \%$ DMSO solvent. Each value is presented as mean \pm SD of three individual experiments; ${ }^{*} p<0.05$ indicates a significant difference from the result for vehicle-treated worms.

Figure $7 \mathrm{~A}$ shows more than $20 \%$ of the worms had stopped moving at $72 \mathrm{~h}$ of treatment with 10,100 and $200 \mu \mathrm{M}$ yakuchinone A, whereas up to $10 \%$ of the larvae ceased movement activity at $12 \mathrm{~h}$ of treatment with $200 \mu \mathrm{M}$. Additionally, the maximum loss of spontaneous movement occurred at a concentration of $200 \mu \mathrm{M}$. Yakuchinone A caused a dose- and time-dependent loss of spontaneous movement. However, the vehicle (0.1\% DMSO) had no effect on AsL3. Approximately, up to $20 \%$ of the larvae were dead at $48 \mathrm{~h}$ at 10,100 and $200 \mu \mathrm{M}$ yakuchinone A (Figure $7 \mathrm{~B}$ ), and up to 35\% and $40 \%$ of the larvae were dead at 48 and $72 \mathrm{~h}$, respectively, including 100 and $200 \mu \mathrm{M}$. Figure $7 \mathrm{~B}$ shows A. simplex mortality was observed to be up $40 \%$ at $48 \mathrm{~h}$ after exposure to 100 and $200 \mu \mathrm{M}$ yakuchinone A, which showed more lethal efficacy than against $H$. nana (Figure 6).

\section{Conclusions}

Yakuchinone A isolated from A. oxyphylla scavenges radicals of biological interest and preventes damage to oxidative stress. The study suggests that yakuchinone A
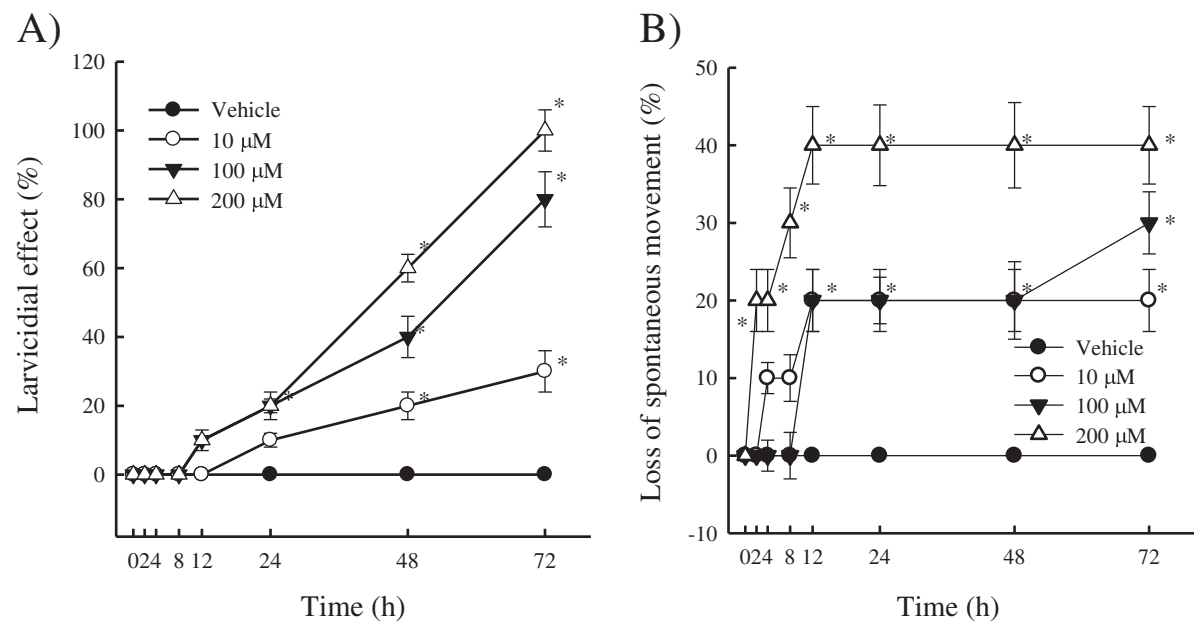

Figure 7 Time course of larvicidal activity A) and loss of spontaneous movements B) of $A$. simplex by yakuchinone A treatment. Effect of yakuchinone $\mathrm{A}(10,100$, and $200 \mu \mathrm{M})$ for $2,4,8,12,24,48$ and $72 \mathrm{~h}$ on third-stage larvae of $\mathrm{A}$. simplex. Vehicle is $0.1 \%$ DMSO solvent. Each value is presented as mean \pm SD of three individual experiments. Statistically significant, ${ }^{*} p<0.05$ indicates a significant difference from the result for vehicle-treated worms. 
inhibits adipocyte differentiation in 3 T3-L1 cells. Treatment with yakuchinone A reduces the intracellular accumulation of neutral lipids and suppresses the induction of leptin and PPARY. Moreover, theses experimental results suggest that inhibition of cell growth by yakuchinone A is more significant for NMSC than for melanoma and noncancerous cells. Following incubation with yakuchinone A in BCC cells increases apoptotic body formation as well as down-regulated $\mathrm{Bcl}-2$, up-regulated Bax, and increased cleavage PARP. Additionally, previous studies have shown that yakuchinone $\mathrm{A}$ has a stronger nematocidal activity of $A$. simplex than cestocidal activity of $H$. nana. These results support the development of selective and efficient natural anthelmintic compounds against helmineth or cestode (Additional file 1). Previous evidence has established that larvicide activity toward $A$. simplex does not depend on scavenging activity, and that free radicals can be harmful to A. simplex, for which the scavenging of these free radicals permits larvae to survive. However, this report is the first to verify that yakuchinone A has the cestocidal activity against $H$. nana, the scavenging activity against $\mathrm{DPPH} \cdot$ and $\mathrm{ABTS} \cdot{ }^{+}$radicals, and the elimination effect on the spontaneous movement of AsL3. Therefore, the radical scavenging activity of yakuchinone A does not reduce its ability to stop the spontaneous movement of AsL3 or its cestocidal activity on $H$. nana. Further investigations must be conducted to elucidate the anthelmintic mechanisms of yakuchinone $\mathrm{A}$ against $A$. simplex and $H$. nana as well as its ability to eliminate the spontaneous movement of $A$. simplex and $H$. nana including their relationships to free radical scavenging activities.

\section{Additional file}

Additional file 1: Yakuchinone $A$ exhibits antioxidative properties, anti-adipocyte differentiation, antitumor activity, and anthelmintic activities against $A$. simplex and $H$. nana.

\section{Abbreviations}

AMPK: Adenosine 5'-phosphate-activated protein kinase; AP-1: Activator protein 1; DMSO: Dimethylsulfoxide; MDA: Malonaldehyde; NMSC: Nonmelanoma skin cancer; ODC: Ornithine decarboxylase; PARP: Poly (ADPribose) polymerase; PPARY: Peroxisome proliferator-activated receptor $\gamma$; ROS: Reactive oxygen species; TBARS: Thiobarbituric acid reactive substances; TNF-a: Tumor necrosis factor-a; TPA: 12-O-tetradecanoylphorbol-13-acetate.

Competing interests

The authors declare that they have no competing interests.

\section{Authors' contributions}

RJL, LPC, HYD, CHL, acquisition of data; analysis and interpretation of data statistical analysis; drafting of the manuscript; obtained funding; study supervision. All authors read and approved the final manuscript. CMY, FYC, administrative support; study supervision. THC, GHW: review of the manuscript. YPT, LW, TWH, HCW, acquisition of data.

\section{Acknowledgements}

The authors would like to thank the National Science Council of the Republic of China, Taiwan, for financially supporting this research under Contract No. NSC 100-2320-B-041-003-MY3 and NSC 98-2320-B-037-014-MY3.

\section{Author details}

'Department of Parasitology, Faculty of Medicine, Kaohsiung Medical University, Kaohsiung, Taiwan. ${ }^{2}$ Department of Chemical and Materials Engineering, National Yunlin University of Science and Technology, Yunlin, Taiwan. ${ }^{3}$ Department of Otolaryngology-Head and Neck Surgery, Kaohsiung Medical University Hospital, Kaohsiung Medical University, Kaohsiung, Taiwan. ${ }^{4}$ Department of Cosmetic Science, Chia Nan University of Pharmacy and Science, Tainan, Taiwan. ${ }^{5}$ Institute of Basic Medical Sciences, National Cheng Kung University, Tainan, Taiwan. ${ }^{6}$ Department of Medical Laboratory Science and Biotechnology, Kaohsiung Medical University, Kaohsiung, Taiwan ${ }^{7}$ Department of Public Health, Kaohsiung Medical University, Kaohsiung, Taiwan. ${ }^{8}$ Institute of Cosmetic Science, Chia Nan University of Pharmacy and Science, Tainan, Taiwan. ${ }^{9}$ Institute of Clinical Medicine, Kaohsiung Medical University, Kaohsiung, Taiwan.

Received: 20 June 2013 Accepted: 23 September 2013

Published: 26 September 2013

\section{References}

1. Jia J, Zhang X, Hu YS, Wu Y, Wang QZ, Li NN, Guo QC, Dong XC: Evaluation of in vivo antioxidant activities of Ganoderma lucidum polysaccharides in STZ-diabetic rats. Food Chem 2009, 115(1):32-36.

2. Alfadda AA, Sallam RM: Reactive oxygen species in health and disease. J Biomed Biotechnol 2012, 2012:936486.

3. Seo JB, Park SW, Choe SS, Jeong HW, Park JY, Choi EW, Seen DS, Jeong JY, Lee TG: Foenumoside B from Lysimachia foenum-graecum inhibits adipocyte differentiation and obesity induced by high-fat diet. Biochem Biophys Res Commun 2012, 417(2):800-806.

4. Hsu CL, Lin YJ, Ho CT, Yen GC: Inhibitory effects of garcinol and pterostilbene on cell proliferation and adipogenesis in 3T3-L1 cells. Food Funct 2012, 3(1):49-57.

5. Cho S, Choi Y, Park S, Park T: Carvacrol prevents diet-induced obesity by modulating gene expressions involved in adipogenesis and inflammation in mice fed with high-fat diet. J Nutr Biochem 2012, 23(2):192-201

6. Lee YK, Lee WS, Hwang JT, Kwon DY, Surh YJ, Park OJ: Curcumin exerts antidifferentiation effect through AMPKalpha-PPAR-gamma in 3T3-L1 adipocytes and antiproliferatory effect through AMPKalpha-COX-2 in cancer cells. J Agric Food Chem 2009, 57(1):305-310.

7. Lee YS, Kim WS, Kim KH, Yoon MJ, Cho HJ, Shen Y, Ye JM, Lee CH, Oh WK, Kim CT, Hohnen-Behrens C, Gosby A, Kraegen EW, James DE, Kim JB: Berberine, a natural plant product, activates AMP-activated protein kinase with beneficial metabolic effects in diabetic and insulin-resistant states. Diabetes 2006, 55(8):2256-2264.

8. Zang M, Xu S, Maitland-Toolan KA, Zuccollo A, Hou X, Jiang B, Wierzbicki M, Verbeuren TJ, Cohen RA: Polyphenols stimulate AMP-activated protein kinase, lower lipids, and inhibit accelerated atherosclerosis in diabetic LDL receptor-deficient mice. Diabetes 2006, 55(8):2180-2191.

9. De S, Adhikari S, Tilak-Jain J, Menon VP, Devasagayam TP: Antioxidant activity of an aminothiazole compound: possible mechanisms. Chem Biol Interact 2008, 173(3):215-223.

10. Chitchang S, Piamjinda T, Yodmani B, Radomyos P: Relationship between severity of the symptom and the number of Hymenolepis nana after treatment. J Med Assoc Thai 1985, 68:423-426.

11. Smyth JD, McManus DP: The physiology and biochemistry of cestodes. Cambridge: Cambridge University Press; 1989.

12. Ito A: Basic and applied immunology in cestode infections: from hymenolepis to taenia and echinococcus. Int J Parasitol 1997, 27(10):1203-1211.

13. Shih HH, Ku CC, Wang CS: Anisakis simplex (Nematoda: Anisakidae) thirdstage larval infections of marine cage cultured cobia, Rachycentron canadum L., in Taiwan. Vet Parasitol 2010, 171:277-285.

14. Karl H, Baumann F, Ostermeyer U, Kuhn T, Klimpel S: Anisakis simplex (s.s.) larvae in wild Alaska salmon: no indication of post-mortem migration from viscera into flesh. Dis Aquat Organ 2010, 94(3):201-209.

15. Takei H, Powell SZ: Intestinal anisakidosis (anisakiosis). Ann Diagn Pathol 2007, 11:350-352. 
16. Gamboa PM, Asturias J, Martínez R, Antépara I, Jáuregui I, Urrutia I, Fernández J, Sanz ML: Diagnostic utility of components in allergy to Anisakis simplex. J Investig Allergol Clin Immunol 2012, 22(1):13-19.

17. Sakanari JA, McKerrow JH: Anisakiasis. Clin Microbiol Rev 1989, 2(3):278-284.

18. Lin RJ, Chen CY, Lee JD, Lu CM, Chung LY, Yen CM: Larvicidal Constituents of Zingiber officinale (Ginger) against Anisakis simplex. Planta Med 2010, 76:1852-1858

19. An LJ, Guan S, Shi GF, Bao YM, Duan YL, Jiang B: Protocatechuic acid from Alpinia oxyphylla against MPP +-induced neurotoxicity in PC12 cells. Food Chem Toxicol 2006, 44(3):436-443.

20. Zhang ZJ, Cheang LC, Wang MW, Li GH, Chu IK, Lin ZX, Lee SM: Ethanolic extract of fructus Alpinia oxyphylla protects against 6-hydroxydopamine -induced damage of PC12 cells in vitro and dopaminergic neurons in zebrafish. Cell Mol Neurobiol 2012, 32(1):27-40.

21. Jang S, Jung JC, Oh S: Synthesis of 1,3-diphenyl-2-propen-1-one derivatives and evaluation of their biological activities. Bioorg Med Chem 2007, 15(12):4098-4105.

22. Flynn DL, Rafferty MF, Boctor AM: Inhibition of 5-hydroxy-eicosatetraenoic acid (5-HETE) formation in intact human neutrophils by naturallyoccurring diarylheptanoids: inhibitory activities of curcuminoids and yakuchinones. Prostaglandins Leukot Med 1986, 22(3):357-360.

23. Surh Y: Molecular mechanisms of chemopreventive effects of selected dietary and medicinal phenolic substances. Mutat Res 1999, 428(1-2):305-327.

24. Chun KS, Sohn Y, Kim HS, Kim OH, Park KK, Lee JM, Moon A, Lee SS, Surh YJ: Anti-tumor promoting potential of naturally occurring diarylheptanoids structurally related to curcumin. Mutat Res 1999, 428(1-2):49-57.

25. Zhang Q, Luo S, Wang H, Fun D: Studies on the chemical constituents of Yizhiren (Alpinia oxyphylla). Zhong Cao Yao 1997, 28:131-133.

26. Liang CH, Chan LP, Ding HY, So EC, Lin RJ, Wang HM, Chen YG, Chou TH: Free radical scavenging activity of 4-(3,4-dihydroxybenzoyloxymethyl) phenyl-O- $\beta$-D-glucopyranoside from Origanum vulgare and its protection against oxidative damage. J Agric Food Chem 2012, 60(31):7690-7696.

27. Chou TH, Ding HY, Lin RJ, Liang JY, Liang CH: Inhibition of melanogenesis and oxidation by protocatechuic acid from Origanum vulgare (oregano). J Nat Prod 2010, 73(11):1767-1774.

28. Thounaojam MC, Jadeja RN, Ramani UV, Devkar RV, Ramachandran AV: Sida rhomboidea. Roxb leaf extract down-regulates expression of PPARY2 and leptin genes in high fat diet fed C57BL/6J mice and retards in vitro 3T3L1 pre-adipocyte differentiation. Int J Mol Sci 2011, 12(7):4661-4677.

29. Naowaboot J, Chung CH, Pannangpetch P, Choi R, Kim BH, Lee MY, Kukongviriyapan $\mathrm{U}$ : Mulberry leaf extract increases adiponectin in murine 3T3-L1 adipocytes. Nutr Res 2011, 32(1):39-44.

30. Chou TH, Liang CH: The molecular effects of aloe-emodin (AE)/liposome$\mathrm{AE}$ on human nonmelanoma skin cancer cells and skin permeation. Chem Res Toxicol 2009, 22(12):2017-2028.

31. Kundu S, Roy S, Lyndem LM: Cassia alata L: potential role as anthelmintic agent against Hymenolepis diminuta. Parasitol Res 2012, 111(3):1187-1192.

32. Iglesias L, Valero A, Benitez R, Adroher FJ: In vitro cultivation of Anisakis simplex: pepsin increases survival and moulting from fourth larval to adult stage. Parasitology 2001, 123:285-291.

33. Kiuchi F, Miyashita N, Tsuda Y, Kondo K, Yoshimura H: Studies on crude drugs effective on visceral larva migrans. I. Identification of larvicidal principles in betel nuts. Chem Pharm Bull 1987, 35:2880-2886.

34. Đorđević TM, Šiler-Marinković SS, Dimitrijević-Branković SI: Effect of fermentation on antioxidant properties of some cereals and pseudo cereals. Food Chem 2010, 119:957-963.

35. Chou TH, Ding HY, Chan LP, Liang JY, Liang CH: Novel phenolic glucoside, origanoside, protects against oxidative damage and modulates antioxidant enzyme activity. Food Res Int 2011, 44:1496-1503.

36. Wu SJ, Ng LT: Antioxidant and free radical scavenging activities of wild bitter melon (Monordica charantia Linn. Var. abbreviate Ser.) in Taiwan. LWT 2008, 41:323-330.

37. Zou Y, Lu Y, Wei D: Antioxidant activity of a flavonoid-rich extract of Hypericum perforatum L. in vitro. J Agric Food Chem 2004, 52(16):5032-5039.

38. Lee MH, Chen YY, Tsai JW, Wang SC, Watanabe T, Tsai YC: Inhibitory effect of $\beta$-asarone, a component of Acorus calamus essential oil, on inhibition of adipogenesis in 3T3-L1 cells. Food Chem 2011, 126:1-7.
39. Chun KS, Kang JY, Kim OH, Kang H, Surh YJ: Effects of yakuchinone $A$ and yakuchinone $\mathrm{B}$ on the phorbol ester-induced expression of COX-2 and iNOS and activation of NF-kappaB in mouse skin. J Environ Pathol Toxicol Oncol 2002, 21(2):131-139.

40. Liang $\mathrm{CH}$, Wang GH, Chou TH, Wang SH, Lin RJ, Chan LP, So EC, Sheu $\mathrm{JH}$ : 5-epi-Sinuleptolide induces cell cycle arrest and apoptosis through tumor necrosis factor/mitochondria-mediated caspase signaling pathway in human skin cancer cells. Biochim Biophys Acta 2012, 1820(7):1149-1157.

doi:10.1186/1472-6882-13-237

Cite this article as: Lin et al:: Antioxidant, anti-adipocyte differentiation antitumor activity and anthelmintic activities against Anisakis simplex and Hymenolepis nana of yakuchinone A from Alpinia oxyphylla. BMC Complementary and Alternative Medicine 2013 13:237.

\section{Submit your next manuscript to BioMed Central and take full advantage of:}

- Convenient online submission

- Thorough peer review

- No space constraints or color figure charges

- Immediate publication on acceptance

- Inclusion in PubMed, CAS, Scopus and Google Scholar

- Research which is freely available for redistribution

Submit your manuscript at www.biomedcentral.com/submit
C BioMed Central 